\title{
Stability of cyclosporin A in human serum
}

\author{
JM SMITH, JM HOWS, EC GORDON-SMITH \\ From the Department of Haematology, Royal Postgraduate Medical School. Hammersmith Hospital, London WI2 OHS
}

SUMmARY Cyclosporin A (CyA), a new immunosuppressive drug, is used for the prevention of organ graft rejection in man. The main side effect of $\mathrm{CyA}$ is nephrotoxicity which is usually reversible when the drug is stopped. Nephrotoxicity may be avoided in patients by careful monitoring of serum CyA concentration by radioimmunoassay, in addition to the routine biochemical tests of renal function. There is a good correlation between trough ( 12 hour) serum concentrations of $\mathrm{CyA}$ and plasma creatinine.

Cyclosporin A was stable in serum at room temperature for up to seven days and on storage at $-20^{\circ} \mathrm{C}$ for up to five months. Delayed separation of blood stored at room temperature led to increased serum CyA concentrations while blood stored at $4^{\circ} \mathrm{C}$ before separation was much more stable.

Blood samples should be separated as quickly as possible to avoid the release of CyA from the cellular fraction into the serum. Haemolysed samples should be avoided. CyA is sufficiently stable at room temperature for serum samples to be sent in the first class post to a control laboratory for CyA assay, after patients are discharged from the transplant centre. Control and patient serum samples should be stored for a maximum of five months at $-20^{\circ} \mathrm{C}$ prior to assay for $\mathrm{CyA}$.

Cyclosporin $\mathrm{A}(\mathrm{CyA})$ is a fungal metabolite with a cyclic structure consisting of 11 amino acids and has a molecular weight of 1202.6 daltons. ${ }^{1}$ The powerful immunosuppressive effect of CyA has been used clinically to prevent rejection of organ grafts in $\operatorname{man}^{2}$ and to prevent graft versus host disease in allogeneic bone marrow transplantation. ${ }^{3}$

Mild nephrotoxicity occurs in most patients treated with CyA and cases of established renal failure have been reported. ${ }^{3}$

We have found careful monitoring of serum CyA concentration using radioimmunnoassay (RIA) useful in the management of bone marrow transplant patients receiving the drug. There is a good correlation between predose (trough) CyA serum concentration and nephrotoxicity which is most apparent when other nephrotoxic drugs are given concurrently with $\mathrm{CyA}{ }^{+}$

Bone marrow transplantation is carried out in specialised centres but after discharge from hospital, patients may be followed up at other hospitals some distance from the transplant centre. It is important that pharmacological monitoring should continue at this stage. The most effective way to continue monitoring patients is for blood samples to be sent by post to the transplant centre where the RIA for CyA is routinely performed.

The purpose of this study was to investigate the stability of CyA in serum on storage under different conditions and to define the best method of handling

Accepted for publication 9 August 1982 blood samples which are sent to transplant centres for assay. In addition we present some data on the long-term stability of $\mathrm{CyA}$ in serum samples stored at $-20^{\circ} \mathrm{C}$.

\section{Material and methods}

Patients were given CyA orally every $12 \mathrm{~h}$. Venous blood was collected from patients just prior to the next dose to measure $12 \mathrm{~h}$ (trough) concentrations of $\mathrm{CyA}$ in the serum. Blood samples were separated at $1100 \mathrm{~g}$ for $10 \mathrm{~min}$ at $4^{\circ} \mathrm{C}$.

MEASUREMENT OF CYA

Cyclosporin A was measured by RIA using tritiated $\mathrm{CyA}$ (H- $\left.-{ }^{3} \mathrm{CyA}\right)$ as a tracer and an antibody supplied in kit form by Sandoz Ltd, Basle. Determinations were performed in triplicate using $20 \mu \mathrm{l}$ serum samples diluted 1/50 with $0 \cdot 05 \mathrm{M}$ Tris buffer, pH $8 \cdot 5 .^{5}$

The interassay variation was $\pm 5 \%$ and the assay was sensitive in the range $60-4000 \mathrm{ng} / \mathrm{ml}$. Concentration of CyA in the unknown samples was calculated from a standard curve. The standard error and $95 \%$ confidence limits $( \pm 2$ SEM) were calculated for each result.

STABILITY OF CYA IN SERUM AFTER DELAYED

SEPARATION OF WHOLE BLOOD

Aliquots of clotted blood were kept at room temperature or $4^{\circ} \mathrm{C}$ for $24 \mathrm{~h}$ before separation. Control samples were separated immediately and stored at $-20^{\circ} \mathrm{C}$. 
STABILITY OF CYA IN SERUM AFTER IMMEDIATE SEPARATION OF WHOLE BLOOD

Storage of serum at room temperature: Clotted blood samples were separated within $1 \mathrm{~h}$ of collection. Fresh serum was aliquoted and kept at room temperature for 24 and $48 \mathrm{~h}$. A control sample was immediately frozen after separation for comparison.

The stability of a previously frozen $\left(-20^{\circ} \mathrm{C}\right)$ serum sample was assessed at room temperature by measuring aliquots of serum left at room temperature for 1-7 days.

Effect officeze-thawing: Aliquots of serum were frozen at $-20{ }^{\circ} \mathrm{C}$ and thawed in a uniform fashion from 1-5 times before assaying for $\mathrm{CyA}$.

LONG-TERM STORAGE OF SERUM AT $-20^{\circ} \mathrm{C}$

The long-term stability of CyA in serum was assessed by storing two sera containing CyA in $200 \mu \mathrm{l}$ aliquots at $-20^{\circ} \mathrm{C}$ for up to eight months. Aliquots were thawed and assayed at regular intervals over this period.

\section{Results}

STABILITY OF (YA IN SERLM AITER DELAYED SEPARATION OF WHOLIE BIOOOI)

Table 1 shows an increase of serum $\mathrm{CyA}$ measured in blood samples stored at room temperature for $24 \mathrm{~h}$ before separation. This effect was greatest in a haemolysed sample $\left(\mathrm{PR}_{1}\right)$ with an increase of $42 \%$ over the control. However, a repeat sample from the same patient $\left(\mathrm{PR}_{2}\right)$ was not haemolysed and only a small increase in CyA (2\%) was seen. CyA is more stable in serum when whole blood samples are stored at $4^{\circ} \mathrm{C}$ before separation (Table 2 ).

STABILITY OF CYA IN SERIN AFTER IMMEDIATE

SEPARATION

Serum at room temperature for 24 and $48 \mathrm{~h}$ was stable whether the samples were freshly separated or frozen and

Table 1 Stability of C iA in serum after delaved separation of whole blood clotted blood at room temperature for $24 \mathrm{~h}$ before separation)

\begin{tabular}{|c|c|c|c|c|}
\hline Patic'nt & Sample' & $\begin{array}{l}\text { Serum } \\
\text { CyA }(\mathrm{ng} / \mathrm{ml}) \\
\pm 2 S E M\end{array}$ & $\begin{array}{l}\text { "\% change' } \\
\text { treated } \\
\text { sample }\end{array}$ & $\begin{array}{l}\text { Visible } \\
\text { hatemolysis }\end{array}$ \\
\hline \multirow[t]{2}{*}{ PR (1) } & a & $170 \pm 27$ & & No \\
\hline & $b$ & $242 \pm 13$ & +2 & Yes \\
\hline \multirow[t]{2}{*}{ PR (2) } & a & $130 \pm 1$ & & $\mathrm{No}$ \\
\hline & $b$ & $133 \pm 5$ & 2 & No \\
\hline \multirow[t]{2}{*}{ WK } & $a$ & $162 \pm 20$ & & No \\
\hline & b & $189 \pm 28$ & 17 & No \\
\hline \multirow[t]{2}{*}{$\mathrm{JC}$} & a & $74 \pm 20$ & & No \\
\hline & $\mathrm{b}$ & $84 \pm 16$ & 14 & No \\
\hline \multirow[t]{2}{*}{ PH } & a & $112 \pm 33$ & & No \\
\hline & $\mathrm{b}$ & $152 \pm 26$ & 36 & No \\
\hline \multirow[t]{2}{*}{$\mathrm{MH}$} & a & $117 \pm 1$ & & No \\
\hline & b & $162 \pm 11$ & 38 & No \\
\hline
\end{tabular}

$\mathrm{a}=$ serum immediately separated and stored at $-20^{\circ} \mathrm{C}$ (control serum). $\mathrm{b}=$ whole blood at room temperature for $24 \mathrm{~h}$ before separation of serum (treated serum).
Table 2 Stability of $C \mathrm{VA}$ in serum after delaved separation of whole blood (clotted blood at $4^{\circ} \mathrm{C}$ for 24 h before separation)

\begin{tabular}{|c|c|c|c|c|}
\hline Patient & Sample & $\begin{array}{l}\text { Serum } \\
C \mathrm{~A}\left(\mathrm{ng}_{\mathrm{g}} \mathrm{ml}\right) \\
\pm 2 S E M\end{array}$ & $\begin{array}{l}\text { Ce change } \\
\text { lreated } \\
\text { sample }\end{array}$ & $\begin{array}{l}\text { Visible' } \\
\text { hatemolysis }\end{array}$ \\
\hline \multirow[t]{2}{*}{$\mathrm{AZ}$} & $a$ & $76 \pm 29$ & & $\mathrm{No}$ \\
\hline & $b$ & $81 \pm 37$ & 7 & No \\
\hline \multirow[t]{2}{*}{ PR } & a & $130 \pm 1$ & & No \\
\hline & $\mathrm{b}$ & $135 \pm 3$ & + & No \\
\hline \multirow[t]{2}{*}{ MS } & $a$ & $204 \pm 36$ & & Nio \\
\hline & b & $174 \pm 62$ & -15 & $\mathrm{No}$ \\
\hline \multirow[t]{2}{*}{ GZ } & a & $340 \pm 1$ & & $\mathrm{No}$ \\
\hline & b & $325 \pm 5$ & -4 & No \\
\hline \multirow[t]{2}{*}{ PR } & a & $98 \pm 10$ & & No \\
\hline & b & $100 \pm 3$ & 2 & No \\
\hline \multirow[t]{2}{*}{$\mathrm{MH}$} & $a$ & $117 \pm 1$ & & No \\
\hline & b & $119 \pm 13$ & 2 & No \\
\hline
\end{tabular}

$\mathrm{a}=$ serum immediately separated and stored at $-20^{\circ} \mathrm{C}$ (control serum). $\mathrm{b}=$ whole blood at $4^{\circ} \mathrm{C}$ for $24 \mathrm{~h}$ before separation of serum (treated serum) thawed before standing at room temperature (Tables 3 and $\stackrel{A}{A}$ 4). Repeated freezing and thawing (Table 4) of serum 음 sample did not affect the stability of CyA as measured by RIA. CyA was stable in a previously frozen serum sample for up to seven days at room temperature (Table 5).

LONG-TERM STABIIITY OF SERLM SAMPIIS

STORED A $\mathrm{T}-20^{\circ} \mathrm{C}$
Aliquots of two serum samples stored at $-20^{\circ} \mathrm{C}$ for up to eight months were assayed. Aliquots stored for more than five months were found to have a significant decrease in measurable CyA $(\mathrm{p}<0 \cdot 01)$. The Figure shows the mean CyA concentration ( \pm 2 SEM) for aliquots measured during several months of the storage period. The mean $\stackrel{\odot}{\triangle}$ percentage binding of tritiated CyA by antiserum for each $\overrightarrow{\vec{P}}$ month is also shown as a measure of the reproducibility of 의 the experimental conditions over the observation period.

\section{Discussion}

Delayed separation of blood causes a rise in the serum CyA concentration (Tables 1 and 2). This change is more

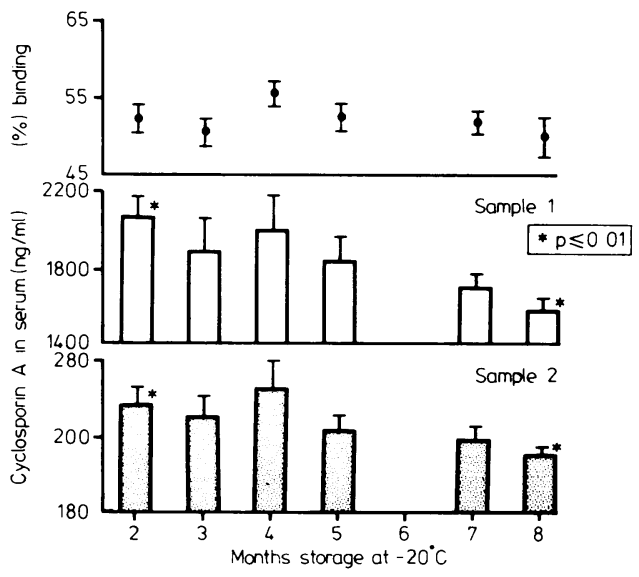

Long-term storage of C VA in serum at $-20^{\circ} \mathrm{C}$. 
Table 3 Stability of CyA in serum after immediate separation (effect of freeze/thawing)

\begin{tabular}{|c|c|c|c|c|c|}
\hline \multirow[b]{3}{*}{ Patient } & \multicolumn{5}{|c|}{ Serum $C_{Y A}(\mathrm{ng} / \mathrm{ml}) \pm 2 S E M$} \\
\hline & \multicolumn{5}{|l|}{ No of times thawed } \\
\hline & I & 2 & 3 & 4 & 5 \\
\hline $\begin{array}{l}\text { WK } \\
\text { SS }\end{array}$ & $\begin{array}{l}242 \pm 31 \\
557 \pm 50\end{array}$ & $\begin{array}{l}259 \pm 14 \\
581 \pm 49\end{array}$ & $\begin{array}{l}259 \pm 14 \\
532 \pm 54\end{array}$ & $\begin{array}{l}289 \pm 44 \\
542 \pm 92\end{array}$ & $\begin{array}{l}286 \pm 16 \\
548 \pm 77\end{array}$ \\
\hline
\end{tabular}

marked when the unseparated blood is left at room temperature than when it is stored at $4^{\circ} \mathrm{C}$. The greatest increase in CyA concentration was noticed in a haemolysed sample (Table 1). It has been shown that $58 \%$ of whole blood CyA is bound to the red cell membrane with $33 \%$ in the plasma fraction ( $\mathrm{T}$ Beveridge, personal communication 1981). This suggests that the rise in serum CyA seen after delayed separation of blood samples is due to release of $\mathrm{CyA}$ from the cellular fraction. Ideally blood samples to monitor serum CyA should be carefully taken to avoid haemolysis just before the drug is given ( 12 hours post dose). Samples should be separated within one hour of collection. If separation is delayed the clotted blood should be kept at $4^{\circ} \mathrm{C}$.

Cyclosporin A appears to be stable on short term storage of serum samples which have been separated immediately (Tables 3-5). Repeated freeze-thawing and storage of separated serum samples for up to one week at room temperature does not affect the measurement of CyA by RIA. Separated serum samples can therefore be sent through the post without freezing, provided reason-

Table 4 Stability of $C y A$ in serum after immediate separation (serum at room temperature for 24 and $48 \mathrm{~h}$ after separation)

\begin{tabular}{llll}
\hline \multicolumn{5}{c}{ Serum CyA $(\mathrm{ng} / \mathrm{ml}) \pm 2$ SEM } \\
Patient & $\begin{array}{l}\text { *Control } \\
\text { sample }\end{array}$ & $+24 \mathrm{~h}$ at room temp & $+48 \mathrm{~h}$ at room temp \\
\hline WK & $242 \pm 31$ & $232 \pm 37$ & $261 \pm 4$ \\
SS & $557 \pm 50$ & $565 \pm 60$ & $580 \pm 4$ \\
AZ & $123 \pm 17$ & $103 \pm 20$ & $113 \pm 25$ \\
GZ & $215 \pm 17$ & $205 \pm 20$ & $211 \pm 7$ \\
\hline
\end{tabular}

*Frozen immediately after separation.

† Room temperature: $\min 21^{\circ} \mathrm{C}$ and $\max 23^{\circ} \mathrm{C}$ for first $24 \mathrm{~h}$.

$\doteqdot$ Room temperature: $\min 19^{\circ} \mathrm{C}$ and $\max 23^{\circ} \mathrm{C}$ for second $24 \mathrm{~h}$. able precautions are taken to avoid bacterial contamination.

Long-term storage of serum samples appears satisfactory at $-20^{\circ} \mathrm{C}$ for up to three months (Figure). However, some deterioration of the samples occurs after this period. These data should be considered when samples are assayed retrospectively and care should be taken to replace quality control samples stored at $-20^{\circ} \mathrm{C}$ every three months.

Cyclosporin A and reagents for the radioimmunoassay were kindly supplied by Sandoz, Basle. J Smith and J Hows are supported by grants from the Leukaemia Research Fund.

\section{References}

' Borel JF, Feurer C. Gubler HU, Stähelin H. Biological effects of cyclosporin A: a new antilymphocytic agent. Agents Actions 1976;6:468-75.

2 Calne RY, Rolles K. White DJG, et al. Cyclosporin A initially as the only immunosuppressant in 34 recipients of cadaveric organs: 32 kidneys, 2 pancreases and 2 livers. Lancet 1979;ii:1033-6.

${ }^{3}$ Powles RL, Clink HM, Spence D, et al. Cyclosporin A to prevent graft versus host disease in man after allogeneic bone marrow transplantation. Lancet 1980;i:327-9.

${ }^{4}$ Hows JM. Palmer S. Gordon-Smith EC. Cyclosporin A and nephrotoxicity in allogeneic bone marrow transplantation. Exp Hematol 1982: 10 [suppl] 10:110-2.

${ }^{5}$ Donatsch P, Abisch M. Homberger M, Traber R, Trapp M, Voges R. A radioimmunoassay to measure cyclosporin $A$ in plasma and serum samples. J Immunoassay 1981;2:19-23.

Requests for reprints to: Miss JM Smith, Department of Haematology, Royal Postgraduate Medical School, Hammersmith Hospital, London W12 0HS, England.

Table 5 Stability of $C y A$ in serum at room temperature for 7 days

\begin{tabular}{|c|c|c|c|c|c|c|c|c|c|}
\hline & & \multicolumn{8}{|c|}{ Days at room temperature } \\
\hline & & 0 & 1 & 2 & 3 & 4 & 5 & 6 & 7 \\
\hline $\begin{array}{l}\text { Serum CyA } \\
(\mathrm{ng} / \mathrm{ml} \pm 2 \mathrm{SEM})\end{array}$ & & $\begin{array}{l}399 \\
\pm 175\end{array}$ & $\begin{array}{l}312 \\
\pm 87\end{array}$ & $\begin{array}{l}394 \\
\pm 31\end{array}$ & $\begin{array}{l}401 \\
\pm 32\end{array}$ & $\begin{array}{l}396 \\
\pm 54\end{array}$ & $\begin{array}{l}374 \\
\pm 21\end{array}$ & $\begin{array}{l}385 \\
\pm 44\end{array}$ & $\begin{array}{l}331 \\
\pm 52\end{array}$ \\
\hline$\overline{\text { Room temperature }\left({ }^{\circ} \mathrm{C}\right)}$ & $\begin{array}{l}\operatorname{Min} \\
\operatorname{Max}\end{array}$ & $\begin{array}{l}18 \\
20\end{array}$ & $\begin{array}{l}18 \\
22\end{array}$ & $\begin{array}{l}18 \\
23\end{array}$ & $\begin{array}{l}20 \\
22\end{array}$ & $\begin{array}{l}19 \\
20\end{array}$ & $\begin{array}{l}19 \\
21\end{array}$ & $\begin{array}{l}19 \\
23\end{array}$ & $\begin{array}{l}19 \\
22\end{array}$ \\
\hline
\end{tabular}

